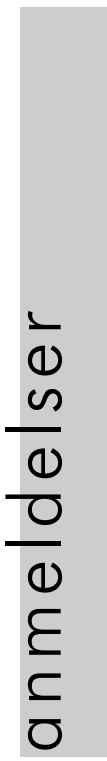

\section{Filosofi som stil}

Ole Fogh Kirkeby: Secunda philosophia, Forlaget Samfundslitteratur, 268 sider, 245 kr.

Titlen på Ole Fogh Kirkebys seneste bog Secunda philosophia signalerer et opgør med prima philosophia. Denne prima philosophia kendetegnes ved, at den ikke tåler, »at der er noget udenfor dens synsfelt. Den vil være perfekt, perfectio, i den forstand, at alt hvad der findes, skal kunne rammes af dens lys." Den perfektion, prima philosophia aspirerer til hos såvel Descartes og Kant - ja, selv Heiddegger ligger ifølge Kirkeby under for denne perfectio-figur -, er uopnålig. Den indsigt må en post-postmoderne eller senmoderne filosofi ifølge Kirkeby besinde sig på for i stedet at blive til en secunda philosophia. Dette søger Kirkeby at virkeliggøre $i$ form af »en fænomenologi, der tematiserer social handlen, hvor hovedvægten lægges et andet sted end på cogito, nemlig på hexis.«

Begrebet hexis er sammen med dets tvillingebegreb steresis et omdrejningspunkt i fremstillingen. Begrebsparret hexis og steresis henter Kirkeby fra Aristoteles. Hexis ligger op ad perfectio-figuren og henviser til det der er helt og nødvendigt: »Det er et 'antibegreb', der virtuelt ophæver modsætningen mellem begreb og virkelighed.« Imidlertid annulleres ophævelsen, idet hexis møder steresis. Steresis er en brudkategori, der handler om 'det andet'. Dette spil mellem identitet og ikke-identitet er den bærende bevægelse i bogens diskussion af forholdet mellem ord, tanke og virkelighed. Dette spændingsfelt kommer for eksempel til syne, når Kirkeby skriver: det at »sproget ikke slår til kan også være en erfa- ring af, at sproget næsten slår til.«

At Kirkeby henter sine grundbegreber $\mathrm{i}$ antikken er en konsekvens af den opfattelse, at filosofiens historie er historien om forvandlingen af den græske filosofis begreber gennem middelalder, renæssance, modernitet og postmodernitet. Fremstillingen lider til tider under følgerne af denne opfattelse, idet Kirkeby ynder at diskutere filologiske detaljer, som ofte distraherer mere end de underbygger den filosofiske bestræbelse. Dette kontrasteres imidlertid af den lethed, hvormed Kirkeby benytter sig af sin idehistoriske kompetence. Med imponerende uimponerethed udvikler Kirkeby sin filosofi i dialog med filosofihistoriens mestertænkere - lige fra Platon til Derrida. En praksis med mange faldgruber, som Kirkeby undgår at falde $i$ takket være sin veludviklede idehistoriske sans for kontekstens betydning. I modsætning til inddragelsen af de filologiske overvejelser serveres de idehistoriske betragtninger med en velgørende autoritet.

Det bør nævnes, at Secunda Philosopbia indgår i et større filosofisk projekt. Mens et disputatsforsvar for nogle er en afslutning, havde Ole Fogh Kirkeby det tilsyneladende lige omvendt med sin afhandling Begivenhed og kropstanke. Enfanomenologisk-hermeneutiskanalyse fra 1994. For den syntes at have være startskuddet til den serie på seks bøger - næsten halvandet tusinde sider - som Secunda Pbilosopbia ifølge forfatteren nu afslutter. Jeg skal ikke her forsøge at forholde mig til dette opus i sin helhed. Blot vil jeg nævne, at Ole Fogh Kirkeby i dette projekt synes båret af en ubændig trang til at filosofere - på egne betingelser.

Indsigten i perfectio-figurens uholdbarhed har som en af sine kon- 
sekvenser, at selve formen bliver lagt under pres. Stilen bliver med indre filosofisk konsekvens helt særegen. »Således må bogens stil selv være u-perfekt, altså sammenstykket, blandet, brudt.« Aforismen, metaforikken og det poetiske sprog er blandt de virkemidler, Kirkeby benytter sig af. Stilen er til tider bevidst dunkel, og paradokset opsøges lige så gerne som det undgås, idet klarhed for Kirkeby ikke er et ideal, der hører til filosofiens væsen. Kort sagt opfattes sproget som utilstrækkeligt. Som Kirkeby advarer i forordet til Om betydning. Tetragrammatonske refleksioner: „Ordene må derfor sættes ind $\mathrm{i}$ modstrid med sig selv. Og det er ensbetydende med et krav om, læseren selv går med til grænsen for den mening, han umiddelbart kan fatte."

Peter Bjørntoft

\section{Vagn Lyhne (red): Ulvens tid. Massemord og sult i Weimarrepublikken.}

Oversættelse, efterskrift \& redaktion ved Vagn Lyhne, Forlaget Klim, Århus 1998, 319 s., illustreret, $285 \mathrm{kr}$.

I årene fra 1918 til 1924 myrdede Fritz Haarmann mindst 27 unge mænd og drenge ved at bide deres halspulsåre over. Alle mordene blev begået i Haarmanns lille tagværelse i byen Hannover.

I Tyskland udkom der i 1995 to bøger om tilfældet Haarmann. Den ene er den kendte jødiske skribent Theodor Lessings samtidige beskrivelse af sagen mod Haarmann, der bygger på en serie avisreportager, og som i 1925 udkom som bog under titlen, Haarmann. Die Gescichte eines Werwolfs. Den anden bog, Die Haarmann-Protokolle, er en udskrift af en række samtaler Haarmann førte med den kendte sindsygelæge Ernst Schultze. Disse protokoller er redigeret og bearbejdet af Christine Pozsár og Michael Farin, der har fundet dem frem fra Niedersächsisches Hauptstaatsarchiv og samlet dem kronologisk i deres 639 siders store bog. Begge bøger blev udgivet som opfølgning af Romuald Karmakers film, Der Totmacher. Götz George, der spillede rollen som Fritz Haarmann, fik prisen som bedste skuespiller på filmfestivalen i Venedig i 1995.

Ulvens tid. Massemord og sult $i$ Weimarrepublikken består af Vagn Lyhnes oversættelse af Theodor Lessings gennemgang af sagen, suppleret med et fyldigt uddrag af samtalerne mellem Haarmann og Schultze. Derudover gengiver bogen Haarmanns "selvbiografi” og afsluttes med Vagn Lyhnes efterskrift, hvor han analyserer Haarmanns livsløb, det homoseksuelle miljø omkring hovedbanegården i Hannover og psykiatrien og justitsens forsøg på at bringe det umådelige under kontrol.

Tore Eriksen

\section{Per Buvik: \\ Georges Bataille.}

Gyldendal Norsk Forlag, Ariadne-serien, Oslo 1998, 144 s., $178 \mathrm{Nkr}$.

Buvik leverer her den første introducerende og sammenhængende præsentation af Batailles værk i Skandi- 